\title{
Role and Impact of Budget as an Instrument of Financial and Developmental Policy in Kosovo
}

\author{
PHD.Cand., Enkeleda Lulaj \\ University "Haxhi Zeka" in Peja \\ Enkeleda.Iulaj@unhz.eu
}

\section{Doi:10.5901/ajis.2015.v4n1s1p61}

\begin{abstract}
In this research paper will be presented a detailed description of the methodology for analysis the budget and the improving connections, and budget planning for the provision of financial and developmental policies in Kosovo. This paper has been written intelligibly, so that could be read and easily understood by non-specialists of field of economics and finance. State budget is one of the most important economic instruments, to have Government of Kosovo in available. Drafting and spending the budget Kosovo has been the competence of local institutions since the establishment of the Provisional Institutions. However, even after more than a decade from the time when local institutions have enjoyed the right to drafting the costs of the state budget, there are major problems in drafting procedures, expenditure and budget reporting. Kosovo budget in some cases is approved hastily and without debate in the Assembly of Kosovo. The current form of appropriations and budget reports is not at that level of detail as to enable the members of the Assembly and citizens understand clearly the way of divisions and expenditure of public money.
\end{abstract}

Keywords: state budget, expenditure, revenue, budget organizations, budgetary allocations, budgetary reporting etc.

\section{Introduction}

Since the establishment of the Provisional Institutions of Self-Government (PISG) in 2001, drafting and approval of Budget of Kosovo (originally known as the Kosovo Consolidated Budget) has been the competence of local institutions. But, the final right of approval, even radical changes until 2008 had been done by the Special Representative of Secretary-General (SRSG) of the UN. Even after the declaration of independence, budget drafting remained exclusive jurisdiction of the state institutions of the Republic of Kosovo. Before the declaration of independence, and in time when local institutions known as PISG, the state budget, in most cases is approved with procedures of accelerated, or even using the powers reserved by the SRSG. Ministry of Finance, as the main institution which coordinates the budget process and budget organizations separately, must be transparent in the publication of detailed budget data. Hence, budget of state plays an important role in the development and economic stability.

\section{The Purpose of the Study}

This paper aims to give an answer to some research questions that relate to strategies that are implemented by the Kosovo budget at central and local level, as well as in all budgetary organizations. The main purpose of this paper is to analyze the existing situation of recognition and the practical implementation of the budget by budget organizations. To realize this scientific paper i am based in public finance literature and practice that has state of Kosovo for planning and approving the budget

\section{Objectives of the Research}

Research objectives related with public finances, specifically the state budget of Kosovo into central and local level, approval of budget, his planning, revenue growth, the classification of expenditures, government grants, budget allocation for municipalities etc. Review of literature on public finances, recognition with strategies budget, formulating and implementing their in practice. Giving clear recommendations about what should be improved in the future Kosovo in order to benefit from the formulation and implementation of strategies for finances, as and tell the issues that may require a more detailed study in the future, specifically for policy of budget. 


\section{Methodology}

During work I used quantitative method of data collection, i.e. questionnaire was used to collect data on the budget. Another method used in this paper is descriptive method, wherewith i have described the strategy that uses Kosovo for budget. And i made comparability between years for the budget, from which field are collected more revenue. As and which is planning for future years for budget.

\section{Reasons for Choosing this Scientific Paper}

The reasons which with have lured to choose this scientific work are:

$\checkmark$ It 'very little in the writings on the role of the Kosovo budget for recent years,

$\checkmark$ Will help all experts in the field of finance at central and local level,

$\checkmark$ Will help students learn more about the Budget of Kosovo,

$\checkmark \quad$ Will learn and many people from different countries of the world for budget of state Kosovo

$\checkmark$ Will help for planning the budget in the future years, and removal of deficiencies,

$\checkmark$ As and for me, will with help to do broader analysis for budget and its function, for a country to develop, because this the scientific paper it's only a beginning of a research for public finance specifically about the budget .

\section{What is State Budget?}

State Budget reflects completely and significantly the policy of government. The budget is essentially a political act. It constitutes the main instrument of the government's economic action and occupies a major place in economy politics of a country. State budget is balanced in terms of receipts and payments. The receipts and payments of general government carried through the single treasury account held in euros and in foreign currencies. Single account of treasury is held at the Bank of Kosovo. Receipts in Kosovo include revenues resulting from mutual transactions and non-reciprocal proceeds from the sale of goods and services, from the sale of long term assets, income from taxes, fees and charges, from exploitation of state-owned assets, from the grants from third parties, by compulsory contributions, from interests, loans, financial transactions, etc. Payments in Kosovo include costs associated with mutual and non-mutual transactions, expenditure for the purchase of goods and services, for purchase or shaping long-term of assets, payments for borrowing, government transfers, grants given to third parties, contributions and donations, financial payments and principal debt ,interest expense, financial rental costs, etc. Budget analyzed in function of Budget classifications as below:

$\checkmark$ Administrative classification, which comprises the classification of general government units until lowest level the spending unit ,

$\checkmark$ Economic classification, the transactions by the nature and / or economic sector,

$\checkmark$ Functional classification, by function or economic and social objectives, that general government units intend to meet,

$\checkmark$ Classification according to the program, which represents programs, subprograms and projects, in accordance with the objectives of general government units ,

$\checkmark$ Classification by sources of funding.

\section{The Budget Process in Kosovo}

Kosovo budget is prepared by the Ministry of Finance (MoF) in coordination with budget organizations and is approved in end of year by the Kosovo Assembly. The budget for next year prepared in the current year through a chain action known as budgetary process. Until in getting a final form as draft bill for budget and before presentation for approval in Parliament, the budget process usually is placed between the Ministry of Finance and budget organizations. The latter, conform instructions from the Ministry of Finance, send their proposals for budget according to the plans and objectives set with work plan. According to the Law on Public Financial Management and Accountability" Budgetary organization means an authority or public enterprise that directly receives an appropriation." In the process of drafting the budget, the Ministry of Finance and budget organizations act between them in two directions: from the bottom up - when budgetary organizations have freedom of the design of costs and budget requirements depending from their plans, and top-down when budget organizations was allocated a budget taking into account the budget and expenditures of the organization 
during the previous year, and not taking into account the needs for budget of organizations budget. As in many countries, Kosovo applies a mixed form of both directions, meaning budgetary organizations prepare or propose their budget for expenditure during the one year (bottom-up direction) but also are limited in this preparation as a result of a budgetary ceiling as recognized in this field (direction top-down).

\section{Reporting of Budget}

Reports of budget expenditures are understood in two ways: the first relates with the reporting of budgetary organizations in the Ministry of Finance, and the second, reporting to all these from the Ministry of Finance to the Assembly of Kosovo. If we refer to the reporting of budgetary organizations in the Ministry of Finance, Law on Public Financial Management and Accountability, and instruction for budget process of preparing based on the law, show a number of mechanisms through which, budgetary organizations report their spending in this Ministry. Financial Management System based on "Free Balance" where all budget organizations have access in it, through the program installed on each organization, is the main tool of reporting of expenditures by budget organizations in the Ministry of Finance. This system also enables organizations to control budget spending through press that makes the software itself through three modes: stop spending, slow down spending, and the need for additional budget allocation.

\section{Budget Appropriations Unclear}

This section examines the problems with the appointment, definition and understanding of budgetary expenditures, in particular those capital. The purpose is to identify some of the typical problems during analyzing budget expenditures and their categorization. A label that occurs notably in budget allocation across municipalities is that large amounts budgetary appointed as "Co-financing with donors" . If we have a look on the budgets for year 2013 for Municipalities, it can be seen that at least 5.5 million of these capital expenditures are appointed in this way. This is a sort of the denomination of general , except that allows the budget manipulation based on the interests of individuals that manage these funds, also creates problems with categorization of expenses if the public is interested to know in what field the government or municipalities have oriented their expenses.

\section{The Revenues Budgetary for the Year 2014}

Based on the analysis of medium-term macroeconomic environment and under the existing parameters, the fiscal policy (parameters these resulting from policies of formulated in accordance with long-term needs of the economy in Kosovo) is done by forecasting budgetary revenues collection for year 2013. The projection for total value of revenue collection resulting from the base scenario assumptions on macroeconomic trends. This forecast represents the starting point for determining the overall level of spending and, consequently for the selection of priority budgetary projects among many requirements to reflect the needs of the economy. In accordance with the legal provisions in Kosovo, the budget preparation process begins by updating the medium-term Expenditure Framework in April of the previous year, and consistently followed by the preparation that lead to final macroeconomic scenario projections two months before the reference period of the annual budget.

\section{Revenue Collected in Country}

Planning for the collection of revenues from tax categories that collected by the Tax Administration of Kosovo (TAK) marks an expansion of $€ 13$ million from the budget of the previous year, and presents an increase of $4.5 \%$ on this basis. The increase in this categories of income, which includes primarily revenues from direct taxes (in personal income, corporate, and interest), as and a portion of indirect taxes (VAT), stems from the projected increase in consumption and investments for the year 2013, which is expected to be translated into increased personal and corporate income, and in value-added from economic activities that support increased consumption and investment.

\section{Collected Revenues in Customs}

In accordance with the basic macroeconomic scenario of 2013-2015, and with observation current trends the so far the collection for year 2012, gross revenues from the border amount in $€ 915$ million during the period January-December 
2013. The assuming of the total realization of revenue at the customs, during the year 2012, the projected growth of this category of revenues reaches to $4.6 \%$.

\section{Other Income of Budget: Non-Tax Revenues; Revenues from Concession Fees from Royalties, Dividends, and Income from Donors}

For the year 2013 budget, the municipal revenues to central level are anticipated to grow $11.5 \%$, from $€ 122 \mathrm{~m}$ to $€ 136 \mathrm{~m}$. Given that the powers of the Central Government are limited to the impact of revenue collection at the municipal level, the municipal level own source revenues are projected at the same level with the previous year for the reasons budgeting, despite the evident increase of nominal GDP, and despite the accumulated potential for the growth of this category of revenues . In 2014, this criterion has been met, and therefore, these revenues have been increased.

\section{Budget Expenditure}

Total budget expenditures for the year 2013, have included, expenses for the AKP and the return of the loan by KEK that are scheduled to be worth $€ 1.586$ million or about $4.0 \%$ higher than planned spending with budget review of the year 2012. This growth the level of spending budgetary for 2013 comes as a result of increased spending on both current as well as capital categories. In this context, current expenditures during 2013 have been increased to about $7 \%$. It should be emphasized the fact that growth with higher of current expenditures for year 2013 compared with the projected growth of capital expenditures, results from two reasons : (I) the significant increase of capital expenditure based (preservation of their high participation in the general costs Medium - Term Expenditure Framework presents coherence, coordination and functional link between the priorities set with the government strategic documents on the one hand, and the involvement their concrete in budgetary projections for the medium- term. For purposes of better orientation of the division of budget funds during the next budget, has been drafted the Statement of Medium-Term Government Priorities 2015-2017, through which is confirmed the commitment of the government in order to give effect to the strategic priorities aiming at sustainable economic growth, setting high standards of good governance and the rule of law, human capital development and improving the living standards and welfare of the citizens of the Republic of Kosovo. Respectively, Kosovo will continue its commitment to the promotion of investment by creating a favorable environment for investment in order to increase the internal and external investment, and to promote economic and industrial revitalization of the country .Support for Small and Medium Enterprises (SMEs) will focus through initiation of the scheme to guarantee loans for start-up businesses and businesses that have the potential for export, policy that also is expected to be supported by development partners. Modernization and infrastructure development constitutes an important element of government investment, which investments have aimed at improving, developing and maintaining transport, aiming Kosovo's integration into the pan-European corridors in line with European standards. Continued support for rural development and agriculture will become through increasing the budget for this sector to the extent of $100 \%$, aiming at advancing the infrastructure for rural development and of agriculture, increase productivity, lowering the import of agricultural products and their replacement with local products, providing advisory services to farmers and also generating new work places. Kosovo Government during the coming period wills to increase the level of employment as strategic goal that attempts to reach not only through this priority but also through the overall development of human resources. Macroeconomic analysis that supports the three-year fiscal plan of elaborating in this document envisages increasing the annual per capita income of EUR 2.960 in 2014, to the 3,276 Euro in 2017. With an average medium-term inflation rate from 1.1\%, and real GDP growth of 4.4\%, macroeconomic performance in subsequent years is expected to be a reflection of the overall increase generating potential of the economy, and not just cyclical movements within existing capacity. Leader of economic growth is expected to be consumption and private investments, followed with support of export and public investment. These predictions are consistent with expected developments in the external sector, namely expectations for acceleration of growth in the economies of the countries with which Kosovo has trade relations, or is concentrated in them, as its Diaspora. Expectations for further economic development based also and in the forecast for further deepening financial of Kosovo's economy, followed with more favorable credit conditions, and overall expansion of deposit portfolios and loan. On this macroeconomic performance and developed budget revenue forecast for the period 2015-2017. Revenues are expected to reach to 1.598 million in 2017, from 1.458 million as are budgeted in the year 2014. Under forecasts for low inflation rate (and falling import prices), this increase that dominated by increased tax revenues are expected to come from increased volume of economic activity. 


\section{Revenues by Source of Cashing}

Budget revenues are expected to have similar structure over the medium-term forecast period, with a gradual increase in participation of local revenue. Due to the joint collection in Value Added from Customs and Tax Administration in Kosovo, the structure of revenues even further to be dominated by customs revenues, with an average participation of $59 \%$. While in the year 2010 the participation of local revenues in general revenues has been 18.5\%, thanks to increased efficiency in the collection of revenues from Kosovo Tax Administration, over the medium term, this share is expected to reach $27 \%$, that proves for a continuing commitment to the implementation of reforms to ensure shift the collection of taxes in the country, in order to ensure a sustainable funding in over the medium term.

\section{Expenditure by Budget Categories 2015-2017}

The budget of year 2014 and medium-term fiscal frames have been prepared by observing parameters allowed by the Law on Public Financial Management and Accountability for the overall deficit. Therefore, based on forecasts for the trend of general budget revenues, overheads are planning to grow at an average rate of $2 \%$ over the medium - term. In spite of this, the level and structure of costs may vary depending on approval and implementation of new legal initiatives and as revenue realization. During the observed period, current cost is expected to account for about $71 \%$ of total expenditures, while capital expenditures represent $27 \%$ of them. The rest of the costs comprise costs for debt servicing and other costs.

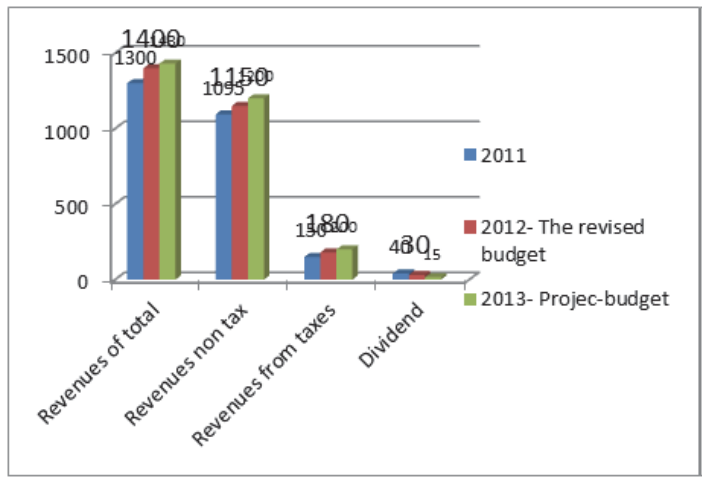

Fig.1. Trend of budgetary revenues in millions.

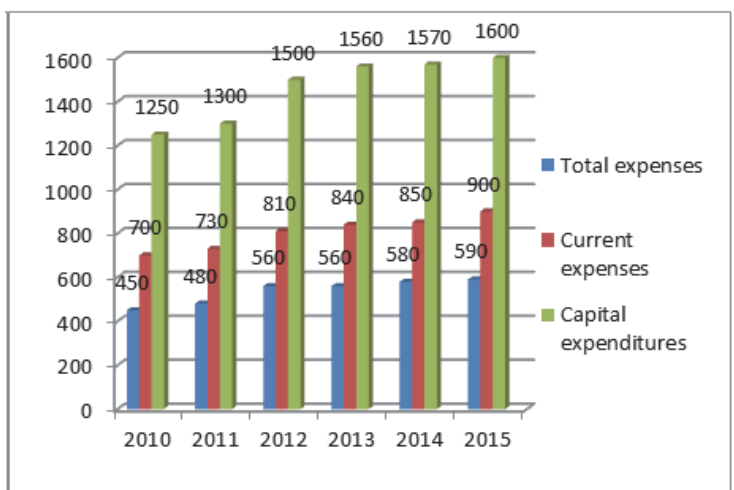

Fig.2. General Budget expenditures in millions.

\section{The Financing}

After the membership the EBRD, EIB and other financial institutions, a part of planned expenditure to be financed from foreign borrowing. As explained above, the assumptions for early implementation of the fiscal rule from the year 2014 upwards is conditional the planning measured of public spending by limiting the growth of the budget deficit to $2 \%$ of GDP. Under the assumption of full execution of expenditure and revenue collection in budget deficit expected in average to reach $2.0 \%$ of GDP . 
Tab.1. Revenues and Expenditures of General Government

\begin{tabular}{|c|c|c|c|c|}
\hline Description & $\begin{array}{l}2012 \text { The Revised } \\
\text { Budget }\end{array}$ & $\begin{array}{c}2013 \\
\text { Budget }\end{array}$ & $\begin{array}{l}\text { Projection for } \\
\text { year } 2014\end{array}$ & $\begin{array}{l}\text { projection for } \\
\text { year } 2015\end{array}$ \\
\hline & \multicolumn{4}{|c|}{ In milion euro } \\
\hline 1. GENERAL REVENUE & 1,384 & 1,423 & 1,426 & 1,498 \\
\hline Revenues from taxes & 1,128 & 1,182 & 1,230 & 1,297 \\
\hline Local Revenues & 288 & 301 & 327 & 359 \\
\hline Customs Revenues & 875 & 915 & 938 & 974 \\
\hline Returns & -35 & -35 & -36 & -37 \\
\hline Non -tax revenues, OSR & 170 & 208 & 195 & 200 \\
\hline Non tax revenues & 46 & 44 & 48 & 49 \\
\hline From Wich : Interest & 2 & 2 & 1 & 1 \\
\hline The own source revenues & 122 & 136 & 115 & 117 \\
\hline Municipal level & 63 & 63 & 64 & 65 \\
\hline Central level & 59 & 73 & 51 & 52 \\
\hline Tax concession & 2 & 6 & 10 & 12 \\
\hline Royalties & - & 22 & 22 & 22 \\
\hline Dividends & 45 & 30 & - & - \\
\hline Budget support & 37 & - & - & - \\
\hline $\mathrm{KE}$ & - & - & - & - \\
\hline BB & 37 & - & - & - \\
\hline Project Grants & 4 & 3 & 1 & 0 \\
\hline 2. Primary spending & 1,524 & 1,586 & 1,650 & 1,666 \\
\hline From wich: AKP & 8 & 8 & 9 & 10 \\
\hline Current & 896 & 959 & 1,001 & 1,009 \\
\hline Wages and Salaries & 410 & 435 & 447 & 449 \\
\hline The goods and services & 204 & 225 & 227 & 229 \\
\hline From which: Utilities & 23 & 23 & 23 & 23 \\
\hline Subsidies and Transfers & 282 & 299 & 327 & 331 \\
\hline Social transfers & 246 & 268 & 296 & 300 \\
\hline Subsidies for NP & 36 & 31 & 31 & 31 \\
\hline Capital Expenditures & 614 & 621 & 636 & 643 \\
\hline from which:costs with regular funding budgetary & & & 528 & 600 \\
\hline imultaneous funding and transfer of under-spending & & - & 108 & 43 \\
\hline Rezervareserve & 3 & 4 & 4 & 4 \\
\hline Net lending & 11 & -6 & - & - \\
\hline From which: loans for PE & 15 & & - & - \\
\hline Returns from PE & -4 & -6 & - & - \\
\hline 3. BALANCE PRIMARY & -140 & -163 & -224 & -168 \\
\hline 3.1 The primary balance (excluding KPA) & -131 & -155 & -215 & -158 \\
\hline 3.2 The primary balance (according to the proposed rule fiscal) & - & - & -116 & -125 \\
\hline Interest Payment & -13 & -18 & -19 & -18 \\
\hline 4. OVERALL BALANCE & -152 & -181 & -243 & -186 \\
\hline 5. FUNDING & 152 & 181 & 243 & 186 \\
\hline External Funding & 93 & 7 & -16 & -26 \\
\hline Withdrawals & 104 & 24 & 7 & 1 \\
\hline From which: IMF & 92 & - & - & - \\
\hline Debt principal repayments & -11 & -16 & -23 & -27 \\
\hline Domestic financing & 60 & 173 & 258 & 212 \\
\hline Internal Borrowing & 75 & 80 & 100 & 140 \\
\hline Funding once & 64 & 326 & 108 & 43 \\
\hline from which: Financial-off revenue & 35 & & 58 & 23 \\
\hline transfer the under spending & - & - & 50 & 20 \\
\hline Modification in other financial assets & -4 & -14 & -3 & - \\
\hline Modification in the stock of OSR & -32 & 3 & 4 & 5 \\
\hline Modification in bank balance & -43 & -222 & 50 & 24 \\
\hline 6. Balance of KCB & 203 & 426 & 376 & 353 \\
\hline From which :ELA & 46 & 46 & 46 & 46 \\
\hline
\end{tabular}




\section{Conclusions and Recommendations}

According to the explanations given above in this scientific paper, it can be concluded that the budget plays a significant role for the state and its functioning. The analysis which has been conducted through the questionnaires for the state budget in the Ministry of Finance and in the municipalities as well has showed that we see revenue growth from year to year. Based on the analysis and graphs, the highest percentage of revenue comes from customs, then revenues from taxes, fees and other income. Through this paper might be learned about the budget of the Republic of Kosovo, as planned, as is increasing from year to year, as are fulfilled the obligations, the cashing of revenues, expenditures classification, what are the gaps in approval and planning the budget, etc. As result, analysis of reporting of budget through the poll of finishes, may recommend that the MFE should be clearer in the design of fiscal policies and in the implementation of the budget that will affect economic growth, should be an avoided budgetary allocation unclear which implies a better budgetary planning. The Ministry of Finance should change the reporting form of budget in quarterly and annual basis. Budgetary reporting should include detailed data on the applicability of all those projects for which are required means with Law on budget.

\section{References}

Https://mf.rks-gov.net/sq-al/ministriaefinancave/buxhetiirepublikessekosoves/buxhetiqendrore.aspx file:///c:/users/enkeleda/downloads/5).tabela_3_1_a_shqip.pdf

https://mf.rks-gov.net/sq-al/ministriaefinancave/buxhetiirepublikessekosoves/buxhetiqendrore.aspx file://c:/users/enkeleda/downloads/buxheti\%202014-2016\%20finale_shqip\%20

https://mf.rks-gov.net/sq-al/departamentet/departamentiibuxhetit.aspx

https://mf.rksgov.net/sqal/ministriaefinancave/raportedhepublikime/kornizaafatmesmeeshpenzimeve.aspx

https://mf.rksgov.net/portals/0/raporte\%20dhe\%20publikime/kash/korniza\%20afatmesme\%20e\%20shpenzimeve\%202015\%20\%202017.pdf

https://mf.rksgov.net/sqal/ministriaefinancave/raportedhepublikime/raportimimujoritehyravedheshpenzimeve.aspx

https://mf.rks-gov.net/sq-al/ministriaefinancave/raportedhepublikime/qarkoretbuxhetore.aspx

https://mf.rksgov.net/sqal/ministriaefinancave/raportedhepublikime/raportetefonditmonetarnderkombetar.aspx

https://mf.rksgov.net/linkclick.aspx?fileticket=mgfelfibt84\%3d\&amp;tabid=194\&amp; mid=1252\&amp;language=sq-al

https://mf.rksgov.net/sqal/ministriaefinancave/buxhetiirepublikessekosoves/buxhetikomunal.aspx

Public Expenditure and Financial Accountability

Assessment of Public Finance Management

For the Republic of Kosovo budget for year 2015

Medium Term Expenditure Framework

The half-yearly report of budget for year 2014

The budget report for year 2013

The Annual Financial Report of the Republic of Kosovo

Monthly reporting of revenues and expenses

Budget Circular 2013- 01 for municipalities

Budget Circular 2014-01 preparations and initial ceilings for the 2014 budget from the central budgetary organizations.

Questionnaires conducted

Data analysis 
